\title{
Alderdommens pædagogisering
}

\section{Samfundsøkonomi, sundhed og individualiserede predagogiske relationer}

\section{Kamilla Nørtoft}

Saxo-instituttet, Københavns Universitet

kamilla.nortoft@hum.ku.dk

Nørtoft, Kamilla (2019). 'Alderdommens pædagogisering: Samfundsøkonomi, sundhed og individualiserede pædagogiske relationer' i Tidsskrift for Forskning $i$ Sygdom og Samfund, nr. 30. 41-66.

Denne artikel handler om pædagogisering af alderdommen og ældre mennesker. Pædagogik forekommer på mange forskellige niveauer, og ofte giver ordet associationer til opdragelse, dannelse og uddannelse af børn og institutionaliserede unge og voksne. Det danske samfunds pædagogiske tiltag overfor ældre mennesker handler oftest om sundhed på den ene eller den anden måde. AEldrepædagogik bliver således til sundhedspædagogik. Det handler om at få folk til at arbejde aktivt på at holde sig sunde og friske for at modvirke den såkaldte xldrebyrde, som ifølge visse diskurser om den demografiske udvikling er som en bombe under vores samfund. Denne diskurs tager udgangspunkt i forestillingen om den naturlige aldring og en medicinsk forståelse af cellernes uundgåelige degenerering. Mens ældre mennesker således fra forskellige sider opfordres til at holde sig sunde og aktive for at udsætte det forestillede forfald så længe som muligt, bliver yngre ældre mennesker også opfordret til at forholde sig til den dag, hvor udsættelsen ikke længere er aktuel, men forfaldet er ind- 
trådt. Dette kan f.eks. ske ved at fremtidssikre deres bolig med fysiske foranstaltninger, der gør den tilgængelig og håndterbar - selv for folk med fysiske funktionsnedsættelser.

I artiklen vil jeg kaste lys over ældrepædagogikken på to niveauer; et politiko-økonomisk niveau repræsenteret ved forskellige former for politiske mål og retningslinjer og et relationsniveau repræsenteret af de medarbejdere, som møder xldre borgere i deres kontakt med velfardssamfundet. De to niveauer er ikke isoleret fra hinanden, og særligt det relationelle niveau er i forskellige grader rammesat af det politiko-økonomiske niveau, som dog alligevel efterlader et vist manøvrerum for mellemmenneskelige relationer $i$ den pædagogiske praksis.

Efter en kort introduktion til ældrepædagogik som felt, der bevæger sig mod sundhedspædagogik, og til eksempler på politikudvikling inden for ældreomsorgen, vil jeg præsentere tre forskellige ældrepædagogiske perspektiver: a) vellykket aldring, b) selvstændig læring og udvikling under vejledning og uddannelse og c) bxredygtig aldring. Jeg vil illustrere de tre perspektiver med eksempler fra forskellige ældrepædagogiske praksis-og fagfelter og vise, hvordan de kan forstås ud fra det politiko-økonomiske og/eller det relationelle pædagogiske niveau. Perspektiverne er baseret på etnografiske studier af ældrepædagogiske sammenhænge, politikker og tværfaglige personaleteams' forståelser af professionelles opgaver og roller i forhold til deres målgrupper. Analysen viser, hvordan pædagogiske tilgange baseres på forskellige værdisæt og måder at at identificere ældre mennesker på.

\section{The pedagogisation of old age: National economy, health and individualised pedagogical relations}

This article is about pedagogicalisation of old age and older people. Pedagogy is found in different contexts and on different levels and the term is often associated with education and childrearing as well as with institutionalised adolescents and adults. In a Danish context, the pegagogical initiatives targeting older people is mostly focusing on health in various ways. Thus, old age pedagogy is turned into health education focusing on motivating older people to stay fit and heathy and to prevent the so-called burden of the elderly, which - according to certain discourses about the demographic development - can be understood as a bomb threatening the welfare society. This discourse takes its point of departure in the understanding of natural ageing and a medical perception of the inevitable degeneration of the cells in the human body. While older people are encouraged to stay fit and healthy to postpone the imagined human decline for as long as possible, younger old people are encouraged to consider a near future when postponing the decline is no longer possible, but has already begun. This can be done by e.g. secure their home for the future making it manageable and easily accessible for people with restricted mobility. 
In the article, I will shed light on old age pedagogy on two levels: a politico-economical level represented by various political goals and guidelines and a relational level represented by the professionals meeting older citizens in a welfare state context. The two levels are not isolated from each other end especially the relational level is to various degrees framed by the politico-economical level. However, there is still some room for individual approaches in the arena of pedagogical practice. After a short introduction to the field of old age pedagogy moving towards health education and examples of policy within the field of public care for older people, I will introduce three perspectives within old age pedagogy: a) successful ageing, b) independent learning and development with supervision and education and c) sustainable ageing. I will illustrate the three perspectives with examples of different practice contexts of old age pedagogy and show how they can be understood from the politico-economical and the relational pedagogical levels. The perspectives are based on ethnographic studies of settings of old age pedagogy, policy and interdisciplinary teams of professionals and their perceptions of their work and roles in relation to older clients, users and residents of their work places. The analysis show how pedagogical approaches are based on different sets of values and ways to identify older people.

\section{Introduktion}

\section{Bevægelse mellem ældrepædagogik og sundhedspædagogik}

Ældrepædagogik er fra et pædagogisk teoretisk perspektiv ikke et stort felt. Det er måske snarere et område, som oftest dækkes af pleje-/sygeplejeområdet og psykologien på forskellig vis. I Sverige er ældrepædagogikken derimod et selvstændigt teoretisk felt med egen uddannelse, som positioneres i grænselandet mellem socialt arbejde, pædagogik og social omsorg (Magnússon 2013).

Helt overordnet omhandler pædagogik både teori og praksis vedrørende "mål, midler, sammenhænge og forhindringer i relation til udvikling af værdier, viden og kunnen" (Den Store Danske) hos individet. Pædagogikkens formål er således ud fra et givent værdisæt at kunne forandre noget hos individet, og det kan gøres på mange niveauer og gennem forskellige virkemidler. Når politikere og policymakers laver lovgivning, retningslinjer og standarder, er det således en måde at pædagogisere i forhold til befolkningen, men pædagogik er også såvel de uddannelses- og undervisningsstrukturer, der vedtages og skabes i et samfund, som de specifikke didaktiske metoder og overvejelser, der ligger til grund for den direkte 
pædagogiske relation mellem to mennesker, hvori den ene skal motivere og understøtte en forandring hos den anden.

Hansen (2000) argumenterer for, at gamle mennesker ikke skal pædagogiseres, fordi de er gamle, men at pædagogiske traditioner, viden og holdninger bør introduceres på områder, der forholder sig til ældre mennesker. Mennesker kan udvikle sig hele livet, men i nogle tilfælde er dette kun muligt gennem forskellige former for støtte, der inddrager overvejelser om livsstadie og deltageres vilkår i den pædagogiske relation. Nielsen (1992) anfører, at socialpædagogiske tiltag ville kunne bidrage til fortsat personlig udvikling og bedre livskvalitet for målgruppen. I dag er en af de største faggrupper, som arbejder pædagogisk med ældre mennesker, social- og sundhedshjælpere og -assistenter. Deres arbejdsfelter ligger inden for plejeopgaver, relationsarbejde og motivationsarbejde, hvoraf de sidste to kræver pædagogiske kompetencer (Liveng 2013).

De institutionaliserede tiltag med ældre som målgruppe, som præsenteres i denne artikel, er eksempler på ældrepædagogik i praksis. Institutioner baseret på pædagogik for ældre mennesker er under fortsat udvikling, men målene er stort set de samme som for 20 år siden, selvom der i dag er meget større fokus på sundhed i ældrepædagogikken end tidligere (Nørtoft 2014).

I modsætning til børne- og voksenpædagogik og livslang læring er ældrepædagogik ikke orienteret mod samfundet og fællesskabet, men kan koncentreres om den personlige udvikling. I denne optik bør professionelle se sig selv som empatiske vejledere snarere end som autoritative pædagoger (Møller 2000). I 2018 er der stor forskel på, hvordan billedet ser ud, alt efter om man ser på ældrepædagogiske institutioner og deres tilgange og forståelser af deres brugere eller på fremherskende diskurser og politikker omkring aktiv aldring og individets ansvar for eget liv og helbred. Der er en stigende tendens til at opfatte alderdommen som en periode med mulighed og pligt for den enkelte til at holde sig aktiv og sund for således at forblive uafhængig af hjælp fra andre i hverdagen. På denne måde flyttes fokus fra ældrepædagogik til sundhedspædagogik, hvilket i stigende grad skal komme såvel samfundet som individet til gode. Det enkelte ældre menneskes personlige udvikling og livskvalitet bliver i dette perspektiv ikke tillagt meget værdi i sig selv. Borgere i Danmark er i disse år således med Tine Fristrups ord "dømt til livslang udvikling" (2010) - et krav om fortsat udvikling, der i høj grad kan relateres til statens forventning om så længe som muligt at undgå eller udskyde, at den individuelle borger bliver en økonomisk og praktisk byrde for samfundet. De positive aldringsmantraer kommer til at stå for noget efterstræbelsesværdigt og 
i modsætning til en anden udbredt forestilling om den demografisk og biologisk betingede 'ældrebyrde' (Nørtoft 2014, Fristrup 2013, Liveng 2013).

\section{Fra ret til pligt i policy}

Ser man på, hvordan offentlige serviceydelser som forskellige former for hjemmehjælp administreres, finder man et skift, der har medført et stort fokus på uafhængighed, som skal opnås gennem aktivitet og hverdagsrehabilitering (Nørtoft 2013). Hverdagsrehabilitering handler om, at borgere skal vurderes og trænes i at klare dagligdagen, før de eventuelt kan modtage praktisk hjælp og pleje i hjemmet. Denne procedure antages at lede til flere uafhængige borgere i længere tid. Jagten på uafhængighed er dog paradoksal, idet en borger, som har brug for hjælp, fratages autonomien til at vurdere, hvad han eller hun har brug for. Principperne forekommer at være baseret på en antagelse om, at folk udnytter systemet ved at holde op med at være aktive og uafhængige, og derfor skal deres behov for hjælp nu vurderes på nye måder, hvis de skal opfattes som legitime modtagere af offentlig hjemmehjælp. Således bliver nye kriterier for tildeling af forskellige offentlige ydelser til en art 'systemets pædagogisering af alderdommen', og velfærdsstaten påtager sig en opdragende og autoritær rolle i forhold til at fokusere på hverdagsrehabilitering og aktivitet (Nørtoft 2014).

Der er dog i ældreplejen indført en ydelse, som peger i en anden retning nemlig den såkaldte 'klippekortsordning'. Med denne ordning kan modtagere af hjemmepleje spare hjemmepleje-tid op og bruge den efter eget valg frem for til en bestemt aktivitet eller ydelse, som f.eks. rengøring. Dette betyder at borgere kan vælge at bruge den opsparede tid med en ansat i hjemmeplejen til ledsagelse i f.eks. svømmehallen, supermarkedet eller på familiebesøg, at drikke en kop kaffe hjemme osv. Således gives noget af autonomien og autoriteten i eget liv tilbage til modtagere af hjemmehjælp.

Ud over aktivitetsparadigmet i hjemmehjælpssammenhæng, tilbydes forskellige former for aktivitetsmuligheder, der relateres til sundhed (Københavns Kommune 2011). Således stilles krav til f.eks. seniorklubber, om at en vis procentdel af deres planlagte aktiviteter skal være sundheds- og/eller træningsrelaterede, hvis de skal indgå i partnerskaber med kommunen. Også dette er en måde for velfærdsstaten at påvirke og rammesætte, hvad der vurderes at være 'det rigtige' og det gode liv for gamle mennesker, og i hvilke retninger, de skal fokusere på fortsat udvikling og vedligeholdelse af kompetencer (Nørtoft 2014). 


\section{Fornyet opmærksomhed på ældrepædagogik}

Både overordnede rammer og en pædagogisk relation mellem f.eks. en plejemedarbejder og et ældre menneske er påvirket af forskellige værdier og niveauer af identifikation. Værdier, ift. hvordan man bliver gammel på den 'rigtige' måde, kan både bygge på et individperspektiv og på et mere overordnet velfærdssamfundsperspektiv, der kan hierarkisere økonomi og livskvalitet forskelligt. De samme værdier er afgørende for, hvordan et individs handlinger og prioriteringer vurderes som ønskelige, eller som noget, der kræver forandring motiveret udefra. Hvis vi vil forstå aldring i det danske velfærdssamfund, er det relevant at se nærmere på, hvordan ældre mennesker identificeres på forskellige måder og i forskellige sammenhænge, og på hvordan denne identifikation påvirker en given pædagogik overfor ældre mennesker i såvel politiske visioner, policy, overordnede rammer og tilbud og pædagogiske relationer mellem det enkelte ældre menneske og f.eks. velfærdsstatens medarbejdere. Forskningsmæssigt er det empirisk relevant at inddrage et mangefacetteret pædagogisk perspektiv på, hvordan alderdommen udspiller sig og forsøges påvirket på forskellige måder i velfærdssamfundet, fordi mange ældre mennesker er afhængige af de rammer og ydelser, som velfærdsstaten stiller til rådighed. Teoretisk set er ældrepædagogik et lille felt, som nok er druknet lidt i, at den typiske medarbejder på ældreplejeområdet er uddannet inden for sundhedsfeltet. Et bredere pædagogisk teoretisk fokus, som strækker sig ud over sundhedsadfærd og standardiserede regimer og retningslinjer, kan bidrage til en udvikling af praksis inden for ældreområdet.

Eksemplerne viser, at udviklingen mod en meget sundhedsfokuseret pædagogisk tilgang ikke nødvendigvis er den, som virker bedst i forhold til overordnede sundheds- og økonomisk politiske mål, hvorfor det kan være relevant igen at udbrede den pædagogiske tilgang til ældre mennesker, som det har været anbefalet tidligere (jf. ovenfor).

Gennem en række empiriske eksempler på ældrepædagogik i praksis og sundhedspersonales refleksioner omkring cases og konkrete situationer med ældre mennesker vil jeg undersøge nogle af de forskellige tilgange, som eksisterer side om side.

Efter en kort gennemgang af empirisk materiale og analytiske perspektiver præsenteres de empiriske eksempler inden for tre overordnede strømninger i det ældrepædagogiske praksisfelt: vellykket aldring, selvstændig læring og udvikling under vejledning og bæredygtig aldring. I analysen lægges der vægt på, hvordan 
identifikation af ældre mennesker og værdier er tæt forbundet med den pædagogiske tilgang, som kan observeres i forskellige situationer og diskussioner.

\section{Metode og analytiske perspektiver}

Empirien, der præsenteres i det følgende, kommer fra forskellige forskningsprojekter om aldring. Jeg trækker således på mit ph.d.-projekt, der handlede om identitet og sociale relationer blandt ældre mennesker i forskellige pædagogiske arenaer: en klub, et kommunalt aktivitetscenter og et senior qigong-hold (Nørtoft 2013). Der indgår i artiklen her også empiri fra et projekt om, hvordan forskellige individer (mor, døtre og barnebarn) fra samme familie oplever processen, omkring at den gamle mor flytter på plejehjem (Nørtoft 2018). Herudover indgår empiri fra et projekt, der handler om, hvordan sundheds- og plejepersonale fra forskellige plejecentre opfatter de samme case-situationer med ældre mennesker forskelligt, og hvordan de relaterer til egne værdier og egen praksis i diskussioner med hinanden om case-situationerne (Nørtoft og Nordentoft 2019). Et sidste studie, som har bidraget med empiri til denne artikel, er en evaluering af Københavns Kommunes projekt Ældres Netværk. Evalueringen blev lavet på baggrund af individuelle interviews og gruppeinterviews med en række deltagere, tovholdere, plejepersonale og projektledere fra udvalgte underprojekter under Ældres Netværk (Nørtoft og Læssøe 2009). Udvælgelsen af empiriske eksempler er således fragmentariske, men kan forhåbentlig sammen illustrere og forklare perspektiver og tendenser inden for ældrepædagogik i policy og praksis.

Empirien afspejler både pædagogisk praksis og værdier blandt forskellige faggrupper af sundhedsprofessionelle, den alternative sundhedsverden i folkeoplysningsregi og den pædagogiske sfære, som dog på ældreområdet i mange tilfælde administreres af kommunale sundheds- og omsorgsforvaltninger. De institutionelle sammenhænge, som aktivitetscenter, seniorklub og plejecentre udgør, viser, hvordan pædagogiske relationer mellem ældre mennesker og professionelle i mange sammenhænge eksisterer inden for rammerne af det danske sundhedssystem og de politiko-økonomiske værdier, der hersker her. Dette understreger blot pointen om, at ældrepædagogik ofte bliver til sundhedspædagogik i Danmark anno $2018 .^{1}$ 


\section{Analytisk metode og perspektiver}

Helt overordnet er analysen guidet af det brede pædagogikbegreb som skitseret indledningsvist. Når jeg refererer til pædagogik, er det således både den pædagogiske relation i praksis, de ydre rammer for denne relation og de forskrifter, retningslinjer og regler, som rammen og den enkelte medarbejder i varierende grad er præget af, og som smelter sammen med mere eller mindre bevidste og teoretiserede værdisæt, der ligger til grund for det hele afhængigt af situation og kontekst.

Et vigtigt underliggende teoretisk begreb i min udvælgelse og analyse af eksempler på pædagogisk forskellige situationer og niveauer er identitetsbegrebet, som formuleret af Jenkins (2008). Dette identitetsbegreb er brugbart, fordi det kan anvendes til at belyse en pædagogisk situation fra flere forskellige perspektiver. Identitet handler om, hvordan individet, grupper og institutioner identificerer sig selv, gerne vil identificeres af andre og bliver identificeret af andre. Det betyder, at identifikation er en kontinuerlig proces, som hele tiden foregår mellem mennesker og forskellige niveauer af grupperinger, organisationer og institutioner (ibid.). I en specifik ældrepædagogisk kontekst betyder det, at ældre mennesker som befolkningsgruppe identificeres på en måde, som informerer policy, der igen er et produkt af, hvordan den specifikke tids politikere, som er ansvarlige for ældreområdet, identificerer sig selv som myndighed på stats- eller kommunalt niveau. Policy påvirker sammen med andre faktorer, som f.eks. værdigrundlag og fysiske faciliteter den praktiske pædagogik, der igen influeres af en lokal institutions ledelse og individuelle medarbejdere. Det er ikke givet, at lokale ledere og medarbejdere deler identifikation af ældre mennesker med de officielt udmeldte værdier på ældreområdet på myndighedsniveau. Det er heller ikke givet, at individuelle medarbejdere identificerer målgruppen for deres pædagogiske praksis på samme måde som deres lokale leder eller kollega gør det. Ældre mennesker identificerer ligeledes sig selv, andre ældre mennesker, personale, ledelse, rammer og myndigheder på forskellig vis, hvilket påvirker deres måde at indgå i en pædagogisk relation. Således udgør enhver specifik pædagogisk relation mellem en medarbejder og et ældre menneske mange forskellige lag af identifikation med sammenfald og forskelligheder.

Eksemplerne i de efterfølgende afsnit er udvalgt, fordi de kan vise noget om samspillet mellem identifikation og pædagogik på et givent niveau eller i en given relation. De overordnede kategoriseringer, jeg har foretaget, er ikke kendte 
pædagogiske retninger eller skoler, som f.eks. kendes inden for børne- og ungepædagogik.

\section{Forskellige perspektiver i ældrepædagogik}

I det følgende vil jeg præsentere de tre forskellige perspektiver på ældrepædagogik: a) vellykket aldring, b) selvstændig læring og udvikling under vejledning og c) bæredygtig aldring for at tydeliggøre og diskutere de særlige logikker og værdier, som kan spores inden for hvert perspektiv.

\section{Vellykket aldring}

Begrebet vellykket (eller succesfuld) aldring bruges oftest i USA, mens aktiv aldring er et mere udbredt begreb i Europa (Paúl et al. 2012, Walker \& Maltby 2012, Lassen og Moreira 2014). De to begreber forbindes ofte med økonomi og sundhed (ibid.), mens et studie af gamle menneskers egne definitioner særligt fremhæver sundhed og aktivitet, men ikke økonomi (Knight and Ricciardelli 2003). I en rapport fra 2002 definerer WHO aktiv aldring som en proces af fortsat deltagelse i sociale, økonomiske, kulturelle, medborgerlige og spirituelle sfærer og optimering af sundhedsmuligheder, deltagelse og tryghed i styrkelsen af ældre menneskers livskvalitet (WHO 2002:12).

Rowe og Kahn (1997) skelner mellem normal aldring og vellykket aldring, hvor normal aldring indebærer forventningen om fysisk og mentalt forfald, mens vellykket aldring er karakteriseret ved minimalt forfald. Denne definition er baseret på kliniske mål og har domineret en side af debatten om vellykket aldring, mens et andet perspektiv har været domineret af en psykosocial aldringsmodel, der fokuserer på livslang tilpasning (Baltes og Baltes 1990).

Ordet positiv bruges ofte til at referere til vigtigheden af eller opfordringen til udviklingen af en positiv attitude i forhold til aldring og alderdom (Hepworth 1995). Mange forskere inden for det socialgerontologiske felt har dog påpeget det problematiske $\mathrm{i}$ at definere aldring som vellykket eller positiv, fordi disse værdisætninger afhænger af subjektive opfattelser (se f.eks. Naaldenberg et al. 2010, Rossen et al. 2008, Knight og Ricciardelli 2003, Algreen-Pedersen 2011). Det understreges, at definitionen af vellykket aldring gennem andres forventninger overser betydningen af individuelle forskelle i hvad der udgør et succeskriterier (Knight og Ricciardelli 2003), og at ældre menneskers egne definitioner af vellykket ald- 
ring kan variere meget fra diverse teoretiske definitioner (Basset et al. 2007). Definitioner af vellykket aldring afhænger af individuelle værdier, som påvirkes af sociale og kulturelle normer i specifikke kontekster (Tate et al. 2003), og det kan være ekskluderende at fokusere for meget på vellykket og aktiv aldring, da det måske ikke giver plads til andre meningsfulde aktiviteter og aspekter af aldring (Adams et al. 2010). I en dansk velfærdsstatskontekst lyder en lignende advarsel og tilføjelse om, at krav om aktiv aldring kan stå i vejen for solidaritetsfølelse og ansvarliggøre svage og syge ældre for deres egen situation (Blaakilde 2012).

Forskning viser, at sociale og engagerende aktiviteter vurderes positivt og forbindes med generelt velvære og tilfredshed i alderdommen, men at mennesker over 75 år deltager i færre aktiviteter end yngre mennesker. Det kan være nødvendigt at tilpasse aktiviteter til opståede funktionelle og sociale begrænsninger (Adams et al. 2010). Et studie af ældre kvinders forståelse af vellykket aldring viste, at mange af informanterne i et vist omfang forstod vellykket aldring som et bevidst valg om at acceptere forandringer og engagere sig positivt $i$ livet og andre mennesker (Rossen et al. 2008). Mens opfattelserne af vellykket aldring varierer ift. individuelle værdier og mål, fandt forskerne, at velbefindende og sundhed var universelle træk. Derfor argumenterer de for, at professionelle i ældreplejefeltet er nødt til at tage individuelle livsmål med i deres professionelle overvejelser (ibid.). Andre forskere fremhæver vigtigheden af individets erfaring med kontrol i eget liv for følelsen af velbefindende, og at det er vigtigt for professionelle at inddrage individuelle erfaringer og forståelser af sund aldring og ikke kun fokusere på sundhedstemaer (Naaldenberg et al. 2010).

\section{Hvordan er man god til at ældes?}

Som det fremgår af de forskellige teoretiske positioner ift. vellykket aldring og lignende begreber, indebærer de en vurdering af individet og dennes aldring. Denne vurdering kan alt efter tilgangen være det aldrende individs egen, eller den kan komme fra forskellige retninger i individets omverden.

I tværfaglige fokusgrupper af sundhedsprofessionelle med tilknytning til et plejecenter viste en kollega og jeg et filmklip med 83-årige Bodil, som bor alene og klarer sig selv i hverdagen (Nørtoft og Nordentoft 2019). ${ }^{2}$ I filmklippet ser man Bodil holde styr på og tage sin medicin og vitaminer, og man hører hende forklare, hvordan hendes muligheder for at få hjemmehjælp og pleje er i det kommunale system. 
Deltagerne i fokusgrupperne lagde som forventet vægt på forskellige ting i den lille film om Bodil, men en markant reaktion var, at Bodil er god til at være gammel. Det var en fysioterapeut, som konkluderede dette og begrundede det med følgende stikord om sit indtryk af Bodil:

"Ro og afklarethed omkring sin livssituation og den fase hun er $i$ i livet. Hun går aktivt ind $i$ at få en god alderdom. Hun har også tænkt frem. Hun virker ikke utryg. Afklarethed omkring alderdommen, fysisk velfungerende, stor egenomsorg."

Andre af de sundhedsprofessionelle bakkede op om denne beskrivelse af Bodil og lagde vægt på, at Bodil er aktiv f.eks. ved at klare praktiske gøremål, ved at holde styr på sin medicin, men vigtigst af alt, fordi hun holder sig orienteret om det offentlige systems muligheder for forskellige serviceydelser, og hvordan modtagere af disse services kandiderer til modtagelsen gennem opfyldning af forskellige specifikke kriterier. Det afgørende i denne sammenhæng er altså, at Bodil har et realistisk forhold til, hvad hun kan og ikke kan, og at hun forholder sig til mulige forringelser i sit funktionsniveau i fremtiden. Og så holder hun sig i gang ved hele tiden at varetage de daglige opgaver, som hun er i stand til. Hun bedømmes af professionelle til at gøre, hvad der forventes af hende ift. at tage sig af sig selv og holde sig orienteret om egne muligheder i velfærdssystemet. Man kan sige, at hun i høj grad lever op til sine forpligtelser over for samfundet og dets politikker. Hun bliver gammel på den 'rigtige' måde. Set i et pædagogisk perspektiv og på baggrund af de regler og rammer, som fysioterapeuten her udtaler sig om, er der således ikke grund til nogen pædagogisk indsats i forhold til Bodil, fordi hun allerede gør lige, hvad der forventes af hende.

\section{Modstridende interesser i vellykket aldring}

Mens Bodil stadig klarer sig selv i sit eget hjem, holder sig i gang og er orienteret om systemets muligheder for hjælp, hvis det skulle blive nødvendigt, er Anna på 98 år flyttet på plejehjem kort inden sin seneste fødselsdag. Set fra et politikoøkonomisk perspektiv er også Anna god til at blive gammel. Hun har boet i sit hjem, til hun nåede en meget høj alder og har kun i det sidste års tid i sin lejlighed modtaget hjemmehjælp til lidt rengøring hver 14. dag og til allersidst til at komme i bad. Herudover benyttede hun sig i den sidste tid af kommunens madordning og fik leveret mad i hjemmet. Hun har altså holdt sig sund og fysisk uafhængig i 
tæt på 100 år, hvilket betyder, at hun ikke har kostet kommunen meget i udgifter til omsorg og pleje.

Situationen ser dog anderledes ud fra Annas døtres perspektiv. Anna har ikke været helt så uafhængig, som systemet måtte formode, idet døtrene har hjulpet Anna en del med forskellige praktiske gøremål. Døtrene er selv kommet op i årene, og den ene lider af Parkinsons, så det har ikke været let at tage det ansvar for Anna, som de gjorde i de sidste år, mens Anna boede i sin egen lejlighed. Den yngste datter Kirsten er særligt kritisk over for Annas forholden sig til sin aldring. Annas afvisning af offentlig hjælp har været en stor byrde for familien, som kunne være blevet aflastet. Kirsten mener ikke, at Anna har taget ordentligt ansvar for sit eget liv, fordi hun i de sidste par år har insisteret på at blive boende i sit hjem uden at tage imod de muligheder for støtte, som samfundet kunne have givet hende. Således er de sidste par år i hjemmet blevet vanskeligere og vanskeligere og mere og mere uudholdelige for både Anna og familien. Set fra det synspunkt har Anna ikke været god til at tackle den fysiske funktionsnedsættelse, hun har oplevet (Nørtoft 2018).

Anna er nu flyttet på plejehjem og oplever det som meget positivt at bo i ordentlige fysiske rammer, få frisk og 'hjemmelavet' mad hver dag og vide, at hun altid kan få hjælp af personalet, hvis hun har behov for det. Men hun var bange for at flytte på plejehjem. Hun ville ikke, og derfor strittede hun imod så længe som muligt (ibid.).

Annas aldringshistorie kan således fortolkes med helt modsatrettede konklusioner alt efter hvis interesser, man holder sig for øje - samfundsøkonomiens eller familiens. Fra Annas eget perspektiv kan man sige, at hun har haft en lang, aktiv og uafhængig alderdom afbrudt af et par år med fortsat dårligere funktionsniveau, hvorefter hun er blomstret op efter at være tvunget til at flytte på plejehjem. Således illustrerer hendes historie fint, hvordan positive aldringsbegreber kan anvendes og bliver anvendt forskelligt alt efter perspektiv. Ift. en pædagogisk relation vil tilgangen afhænge af hvilke værdier, der vægtes højest. Er det vigtigste, at samfundet sparer penge, og Anna selv vælger at leve under dårlige forhold, og familien føler sig overbelastet, fordi Anna ikke vil flytte på plejehjem? Er det vigtigere, at Anna får mere offentlig hjælp i hjemmet mod sin vilje for at aflaste familien? Eller er det vigtigst, at Anna hjælpes til at forholde sig til sit forringede funktionsniveau og til at afmystificere plejehjemmet, så det fremstår som en mindre uønsket løsning på en uholdbar situation? Interesserne er mange og forskelligartede og vil derfor påvirke en pædagogisk indsats over for mennesker som Anna i meget forskellige retninger. 
Vurderingen, af hvad der er det rigtige at gøre i forhold til både Anna og Bodil, beror på både perspektiver og værdier, som har indflydelse på identifikationen af såvel det enkelte individ og identifikation af en forestillet 'ideel' ældre person.

\section{Selvstændig læring og udvikling under vejledning}

Et perspektiv, der fokuserer på selvstændig udvikling under vejledning, læner sig tæt op ad de ældrepædagogiske formål og værdier, som blev foreslået af Nielsen (1992), Hansen (2000) og Møller (2000) og beskrevet i starten af artiklen.

Denne tankegang har fokus på individets behov og på udvikling i forhold til disse behov på den ældre persons egne præmisser. I denne tankegang er selvudvikling og læring for individets egen skyld i højsædet, mens økonomiske interesser og sundhedsdiskurser ikke har værdi i sig selv. Således er den professionelles rolle i den pædagogiske relation ikke styret af ydre normer for, hvad der har værdi. Den professionelle bør derimod være styret af empati i forhold til den ældre persons værdier og udviklingsmål (jf. Møller 2000).

I dag kendetegnes ældrepædagogikken af arbejdet med forebyggende interventioner, og livslang læring er et centralt begreb. Målet med ældrepædagogikken er at arbejde mod individets livskvalitet, og indsatsen er ofte forebyggende i forhold til de ældre mennesker, som har brug for ekstra støtte. Ældrepædagogikken som selvstændigt felt har således en ambition om at fremme ældres muligheder for holdbar integration i samfundet, idet ældre mennesker ofte sættes uden for samfundet i pensionisttilværelsen og gennem forekomsten af alderistiske stereotyper og fordomme (Magnússon 2013).

\section{En individuel tilgang i en kollektiv kontekst}

I mit ph.d.-projekt om sociale relationer og sundhed i forskellige pædagogiske kontekster fulgte jeg bl.a. et senior-qigong-hold. Holdet mødtes en gang om ugen $i$ en seniorklub og lavede qigong sammen under ledelse af en instruktør (Nørtoft 2013). Træningen forløber ens hver gang startende med kort samtale og te efterfulgt af meditation. Herefter følger en pause med mere snak og te, inden det faste program med fysiske bevægelser bliver gennemført (se Sagli, 2008 for detaljeret beskrivelse af bevægelsesprogram). Nye deltagere vænner sig langsomt til programmet, meditationen og bevægelserne. Alle deltagere får ved start en $\mathrm{cd}$, som kan guide dem gennem en kort afslapning og bevægelsesprogrammet hjemme, hvis de har lyst til at lave qigong udover den kollektive træning med holdet. 
Instruktøren er også uddannet sygeplejerske og ansat i det offentlige sundhedssystem. Dette betyder, at hun giver sundhedsråd og forklaringer fra forskellige medicinske paradigmer og diskurser og kan oversætte fra et medicinsk sprog til et andet og også til lægmandsforklaringer. Således tilbyder hun forskellige fortolkningsrammer for og løsninger og svar på deltageres problemer og forespørgsler. Hun fremhæver, at målet med qigong er et godt helbred. Dette inkluderer både soma og psyke i qigongs sundhedsbegreb: Biyunmetoden styrker kroppens egne helende kræfter og understreger således deltagernes egne helbredelsesstrategier.

Med et særligt senior program er det tydeligt, at der inden for den såkaldte Biyun-metode ${ }^{3}$ trækkes på en forestilling om ældre mennesker som en særlig gruppe. Deltagere identificeres dog ikke på baggrund af kronologisk alder eller social position. Identifikationsprocessen er ikke fastlagt, men derimod mulig at forhandle og er hovedsageligt baseret på forståelsen af fysisk funktionsniveau som noget foranderligt. Selvom en person kategoriseres som ældre gennem rekruttering og deltagelse i seniorprogrammet, er det ikke sikkert, at vedkommende forbliver ældre, hvis ældre er dem, som går i seniorprogrammet. Instruktøren giver et eksempel på dette:

"Hvem der inkluderes som senior afgøres af instruktør og deltager i frllesskab. En relativt ung kvinde på 70, som lærte jichu gong,, men fandt det for svært, deltager nu i senior qigong. Jeg spurgte, om hun ville prove, og hun har det godt med det. Hun vender måske tilbage til jichu gong, når hun har fået mere styrke."

Formålet er at helbrede og styrke, og individers udsigter til forbedring af deres generelle helbred, velvære og funktionsniveau guider synet på deltagerne. De anses for at have mulighed for at samle kraft til at handle og skabe positive forandringer i deres liv.

Instruktøren er opmærksom overfor deltagerne som individer og som gruppe. Hun skal ikke bruge meget energi på programmet, når deltagerne kender det, så hun kan fokusere på deres forskellige behov. Dette styrker deres tillid til hende. Hun forklarer f.eks.:

"Har du lagt mærke til, hvor meget de nyder at blive rørt ved? Jeg prøver at nå rundt til dem alle sammen hver gang og massere deres nyreområde, hoor de ikke kan nå med deres egne hænder. Når jeg har givet dem individuel massage efter timerne, er de helt afslappede og åbne. Så deler de historier, som de ellers ikke deler med holdet." 
Instruktøren er loyal over for både qigongs principper og for deltagerne. Hun respekterer deres individuelle måder at integrere qigong i deres hverdagsliv (eller ikke) og bifalder forskellige strategier og sundhedsrelaterede adfærd såvel som deres interaktion med sundhedssystemet i velfærdsstaten. Det vigtigste forekommer at være refleksion over, hvad der føles rigtigt for individet - også når det går imod officielle anbefalinger fra kommune, stat og sundhedssystem eller imod anbefalinger i den traditionelle kinesiske medicin.

Alle anbefalinger må overvejes i et større perspektiv fra individers hverdagsliv. Individer er forskellige, og derfor må anbefalinger også være det. Instruktøren præsenterer aldrig forskellige forklaringsmodeller i et hierarki. Hun tilbyder dem, og det er op til deltagerne at vælge, hvad de kan bruge og ikke bruge i deres eget liv.

Forståelsen af alderdom trækker primært på funktionsniveau for den enkelte ældre person, men også andre aspekter af aldring tages i betragtning, hvilket f.eks. ses ved en fremhævelse af seniorinstruktørers fremskredne alder for forståelsen af aldringsprocesser og -forandringer. Senior-qigong-instruktører skal således helst være over 60 år. Instruktøren identificerer deltagerne som individer med forskellige liv og behov og ikke mindst som voksne, der er i stand til at tage de bedste valg og beslutninger i deres egen hverdagslivskontekst.

Med sin tilgang til de enkelte deltagere på senior-qigong-holdet læner instruktøren sig tæt op ad de anbefalinger til ældrepædagogik, som tidligere er blevet fremført (Nielsen 1992, Hansen 2000, Møller 2000 og Magnússon 2013) med fokus på, hvad der giver mening i det enkelte aldrende menneskes liv og livsomstændigheder frem for på, hvad der forventes at være mest rentabelt for samfundet.

\section{Individuel støtte til opfyldelse af fælles mål}

Et andet perspektiv på selvstændig udvikling under vejledning finder vi i føromtalte fokusgrupper med forskellige sundhedsprofessionelle. I et videoklip om Benny, som spiller billard på et kommunalt aktivitetscenter sammen med andre medlemmer, ser man medarbejder Hanne føre pointregnskab på en tavle og guide Benny, da det er hans tur til at spille.

Mange fokusgruppedeltagere bliver optaget af Hannes rolle i forhold til Benny. En aktivitetsmedarbejder mener, at det er helt forkert af Hanne at føre pointregnskabet, for det mener hun, at spillerne selv burde gøre. Hanne burde blive i baggrunden og lade spillerne selv facilitere spillet. En fysioterapeut mener, at Hanne overtager spillet og komplimenterer Benny, som var han et barn. Samtidig giver 
fysioterapeuten udtryk for, at Hanne sandsynligvis har intentioner om at være en god hjælper. En ergoterapeut mener, at Hanne får rammesat aktiviteten, så Benny næsten kun kan fejle, fordi han ikke rammer kuglen præcist efter hendes anvisning. Hun mener, at Hanne måske prøver at kamuflere Bennys lidet imponerende billardspil.

De sundhedsprofessionelles optagethed og vurdering af, hvad der foregår omkring billardbordet mellem Hanne og spillerne, afspejler et andet syn på, hvordan den pædagogiske relation mellem den professionelle og det ældre menneske bør være, end det er tilfældet hos qigong-instruktøren. De orienterer sig ikke så meget efter mulige individuelle behov, men bedømmer situationen ud fra aktivitetsparadigmet (Thomasen 2009). Der er i deres vurderinger en underforstået antagelse om, at støtte til selvhjulpenhed er Hannes primære formål, og kun ved at blive tvunget til selvstændigt at udvikle sig - og i dette tilfælde sit billardspil - kan Benny komme tættere på det selvstændighedsmål, som de anser for at være det vigtigste i den pædagogiske relation og i den 'rigtige' måde at udleve sin alderdom på.

Samtidig er alle fokusgruppedeltagere dog enige om, at Benny ikke er særligt interesseret $i$ at spille billard, men derimod nyder den sociale arena, som udgøres af billardspillet og deltagerne. Således vurderer de ikke Bennys formål med deltagelse i aktiviteten i sammenhold med deres vurdering af Hannes pædagogiske valg. De repræsenterer primært bevægelsen mellem ældrepædagogik og sundhedspædagogik, og ifølge deres sundhedspædagogiske overbevisning bør aktiviteten og medarbejderens formål være udvikling mod selvhjulpenhed snarere end socialt samvær for samværets skyld. Set i det lys repræsenterer fokusgruppedeltagernes vurderinger af situationen det politiko-økonomiske niveau, som de mener, bør have mere plads i den mellemmenneskelige og pædagogiske relation mellem Benny og Hanne. For dem er det ikke Bennys egen lyst til at tale med de andre deltagere i billardforummet, som skal have første prioritet. Det er derimod et mål om at være så uafhængig af Hannes hjælp som muligt.

De to eksempler på pædagogiske tilgange og overvejelser viser en stor forskel i identifikationen af ældre mennesker. Hvor hver enkelt ældre menneske på qigongholdet anses for at være et autonomt menneske med kompetencer til at tage ansvar for, hvad der er bedst for ham eller hende, identificeres Benny af de forskellige sundhedsprofessionelle som et menneske, der ikke er i stand til at vurdere, hvad der er bedst for ham selv. De tolker således Bennys eget formål med aktiviteten på en måde, men vurderer, at der pædagogisk bør være fokus på noget andet, som bedre kan opfylde et samfundsøkonomisk formål med fysisk selvhjulpenhed. 


\section{Bæredygtig aldring}

Bæredygtighed forbindes ofte med miljø- og klimaspørgsmål, og i sammenhæng med aldring og alderdom sættes begrebet tit i forbindelse med økonomi, pensionssystemer og sundhedssystemer ${ }^{5}$. Det knytter sig til forestillingen om ældrebyrden, der kan sprænge velfærdssamfundet itu (Fristrup 2010, Liveng 2013), hvis ikke sundhedssystemet og pensionssystemet justeres efter væksten i den ældre andel af befolkningen. Det forekommer dog, at individet let glemmes i dette regnestykke, da mange af strukturændringerne som nævnt har den konsekvens, at individet får frataget autonomien til at vurdere, hvilken hjælp han eller hun har mest behov for.

Orden 'bæredygtig' betyder ifølge Den Danske Ordbog noget, "som sikrer eller indebærer holdbare positive resultater (i en bestemt henseende) uden at ødelægge det foreliggende grundlag". Således kan bæredygtighed fint knyttes til den overordnede præmis, om at pædagogik handler om at støtte eller motivere forandring $i$ en given retning eller mod et givent mål. Bæredygtigheden handler om holdbare positive resultater, men siger i sig selv ikke noget om retningen, ligesom pædagogikbegrebet i sig selv ikke har en bestemt retning. Både i forhold til bæredygtighed og pædagogik lægges retningen således efter nogle mål og værdier, som kan være forskellige alt efter, hvem der sætter dem.

Vælger man derimod at se på bæredygtighed fra et individperspektiv, er de to niveauer ikke nødvendigvis modstridende. Et eksempel på, hvordan sammenhængen mellem det individuelle niveau og samfundsniveauet kan spille sammen på en bæredygtig måde ses f.eks. hos Oplevelsesklubben i Samvirkende Menighedsplejer ${ }^{6}$, som i en projektperiode modtog økonomisk støtte fra projektet Ældres Netværk (Nørtoft og Læssøe 2009). Oplevelsesklubben mødes en gang om ugen og tager på tur sammen til et på forhånd bestemt sted - f.eks. et museum. Transporten foregår med pensionistkort. De mødes til en fælles kop kaffe og afslutter med at spise deres medbragte madpakker i Samvirkende Menighedsplejers lokaler i Valby. Den økonomiske støtte består af tilskud til dyrere entréer og rundvisninger. Deltagerne selv betaler $20 \mathrm{kr}$. for kaffe og lokale at mødes i før og efter oplevelsesturen. Flere af deltagerne knytter deres deltagelse i Oplevelsesklubben sammen med deres sundhed og belastning af sundhedssystemet. To af deltagerne formulerer det således: 
"Vi ender søreme på hospitalet, og det er altså dyrere, hvis ikke der bliver ved med at blive puttet penge $i$ det her område. Det er lige før, man fär lyst til at tage sin seng med herhen bare ved tanken."

"Det er jo fordi, at vi klarer os selv, at vi holder os friske. Kommunen sparer en masse penge ved, at vi kommer her. Hvis forebyggerne kendte til tilbuddene, kunne de udbrede budskabet om aktiviteter."

Ikke blot deltagerne i Oplevelsesklubben, men også konsulent hos Samvirkende Menighedsplejer laver en kobling mellem deltagernes sundhed og deltagelse i projektet:

"Det har nære relationer til sundhed, at der findes sådan noget her.

Det ved jeg, og det er rigtig. Man skal have fat i folk fra begyndelsen. Ellers sidder de bare derhjemme."

Oplevelsesklubben er baseret på frivilligt arbejde og aktiv deltagelse, og så ydes der støtte og sparring fra en konsulent i Samvirkende Menighedsplejer, hvis det er nødvendigt. Umiddelbart synes pædagogik fraværende både på et relationelt og et økonomisk-politisk niveau i forhold til oplevelsesklubben. Ud fra et bredt pædagogisk perspektiv kan man dog argumentere for, at det, at der er nogle fysiske og organisatoriske rammer til stede, som muliggør Oplevelsesklubbens eksistens og beståen, kan anses for at være et pædagogisk greb. I en institution som Oplevelsesklubben er der tillid til, at de frivillige tovholdere og deltagere kan tage vare på hinanden og på gennemførelsen af det ugentlige arrangement, men hvis det er nødvendigt, er der et bagland i form af konsulenten til at støtte og sparre.

Deltagerne selv anser næppe Oplevelsesklubben for at være en pædagogisk institution, men der er ingen tvivl om, at de opfatter deres deltagelse som et vigtigt element i forhold til at opleve hverdagen som god. I den optik kan man sige, at deltagelse i Oplevelsesklubben er en del af lige præcis disse menneskers bæredygtige aldring. Oplevelsesklubben er med til at holde dem i gang på en måde, som både er social, mentalt og fysisk funktionsbevarende, men deres deltagelse er drevet af lyst til samvær og oplevelser snarere end pligt til funktionsbevarelse. På den måde er Oplevelsesklubbens eksistens og deres egen deltagelse i den bæredygtigt for både dem selv, hinanden og for samfundet. 
Mens Oplevelsesklubben er for folk, der ikke behøver massiv professionel hjælp og støtte i hverdagen, er plejehjem i modsætning hertil for folk som ikke kan klare sig selv i eget hjem. Nogle plejehjemsbeboere har kun fysiske funktionsnedsættelser, mens andre har mentale funktionsnedsættelser og ofte også fysiske funktionsnedsættelser. Plejepersonale på plejehjem har mange fast definerede og konkrete opgaver, der skal nås i løbet af arbejdsdagen, mens aktivitetsmedarbejdere har lidt mere spillerum til at tilrettelægge forskellige aktiviteter på forskellige måder for plejehjemmets beboere.

Dette blev tydeligt $i$ en af de førnævnte tværfaglige fokusgrupper, hvor en aktivitetsmedarbejder forklarede sin pædagogiske tilgang til plejehjemmets beboere:

"Jeg læser ikke om borgerne [i deres journaler]. Det vigtige er, hvad de vil i øjeblikket. [...] Hvor tit bliver folk spurgt, hoad de vil lige nu? Måske er ønskerne $i$ dag anderledes end det, der blev skrevet for længe siden. Måske elsker hun [en vilkårlig beboer] ikke kaffe i dag [selvom det står i journalen]. [...] Mange vil gerne noget andet, end de har gjort hele deres liv. I madklubben er det ikke de tidligere køkkendamer, men andre som gerne vil lave mad."

Denne aktivitetsmedarbejder har meget fokus på den enkelte beboer og hans eller hendes ønsker, men hans rammer for arbejdet er anderledes end plejepersonalets og terapeuternes. Han har bedre tid til at lytte til hver enkelt beboer, som kommer i aktiviteten og har større manøvrerum til at tilpasse aktivitet og tilgang $i$ arbejdet. Så vidt muligt er beboerne i fokus frem for fastlagte procedurer og behandling, og han har tid til at prøve sig frem:

"Jeg har kontakt til de andre medarbejdere, men jeg vil hellere høre beboerne om deres egne behov end at hore om deres behov fra det andet personale. [...] Jeg prøver altid at dreje fokus i aktiviteten vak fra sygdom. Selvom jeg har medicinkursus og er assistent, er det ikke derfor, jeg er her. Jeg prover ikke at se sygdomme. Jeg ser ikke Inge som dement, men som Inge, der ønsker at lave noget. Hun har meldt sig til madklub. Hun er god til at læse op, så hun læser opskriften, og de andre ved, at det er det, hun bidrager med. Det er hendes ressource. Folk kan og vil altid et eller andet." 
I den økonomisk-politiske logik er der fokus på, at folk skal udnytte deres ressourcer, men forskellige visitationskriterier og det fremherskende aktivitetsparadigme bestemmer, hvordan det enkelte ældre menneske skal bruge sine ressourcer. Aktivitetsmedarbejderen her har dels friere rammer for sit arbejde end plejepersonalet på samme arbejdsplads, men han har også et helt andet fokus. Selvom han er enig i værdien i, at mennesker udnytter deres potentiale og ressourcer, prøver han ikke at påvirke beboerne på plejehjemmet til at udnytte dem på en på forhånd fastsat måde. Hans erfaringer viser, at denne frihed og værdsættelse af behov og ønsker i øjeblikket, hvor de mødes i en pædagogisk relation, er motiverende for plejehjemsbeboerne. De har lyst til at være med i aktiviteter, og ethvert bidrag bydes velkomment. Åbenhed og plads til tilfældigheder og variationer fra dag til dag betyder, at føromtalte Inge i aktiviteten er begyndt at spise almindelig mad og drikke af en almindelig kop, hvorimod hun i plejeafdelingen spiser blendet mad og drikker af tudkop. I dette konkrete eksempel viser aktivitetsmedarbejderens pædagogiske tilgang til at møde mennesker og deres ønsker og behov lige nu at have positiv indflydelse på Inges selvhjulpenhed, som ikke har været set i plejeafdelingens arbejde med Inge. Den mere professionelt styrede og konkret formålsbestemte tilgang på plejeområdet har snarere fastholdt Inge i afhængighedsrutiner end at hjælpe hende ud af dem. I denne situation producerer den standardiserede tilgang med fokus på uafhængighed altså ikke det, den hævder at gøre.

\section{Et pædagogisk puf i klubben}

I en københavnsk seniorklub, hvor jeg lavede feltarbejde i forbindelse med mit ph.d.-projekt ${ }^{7}$, varetages den daglige drift relateret til medlemsadministration og mange aktiviteter af frivillige medlemmer af klubben. En lønnet leder af klubben har det overordnede økonomiske ansvar og kontakt til kommunen, med hvilken klubben har en driftsoverenskomst. Klubben er ikke bemandet eller gearet til at yde særlig støtte til medlemmerne. Den udgør primært nogle fysiske og strukturelle rammer, som medlemmerne må udfylde efter interesse og engagement. Dette er dog ikke ensbetydende med, at lederen ikke laver pædagogisk arbejde. En stor del af den pædagogiske indsats handler om at 'nurse' de frivillige eller at få medlemmer til at engagere sig som frivillige i klubben. Et eksempel på dette er Kajs rolle som klubbens altmuligmand. Kaj meldte sig ind i klubben for at få adgang til stedets fitnessfaciliteter. En dag spurgte lederen, om Kaj ville hjælpe med at male balkonen, hvilket Kaj indvilgede i. Senere skulle et bordtennisbord samles, og herefter var det et arbejdsbord til klubbens værksted, der skulle samles. Efter dette 
havde Kaj fundet sig til rette i en handy man-rolle i klubben og begyndte at varetage mere faste opgaver som eksempelvis at åbne klubben om morgenen og sætte den første kande kaffe over. Kaj begyndte hurtigt at betragte sine opgaver i klubben som et arbejde, han holdt fri fra om fredagen, men passede på faste tidpunkter i ugens andre hverdage. Det frivillige arbejde gav Kaj meningsfuldt indhold i hverdagen i årevis samt et tilhørsforhold til klubben og de andre medlemmer. For klubben og de andre medlemmer betød Kajs funktion som altmuligmand, at en masse praktiske opgaver forbundet med klubbens daglige drift blev varetaget af en person, som de kunne regne med, og som tog ansvaret for dem på sig. Det var bæredygtigt for både Kaj, klubben og de andre medlemmer, men det krævede et pædagogisk puf og blik, for hvad der kunne vise sig at blive meningsfuldt for Kaj, fra lederens side.

Et andet eksempel på et pædagogisk puf foranlediget af lederens blik for de enkelte klubmedlemmer og de sociale dynamikker i klubben handler om Marianne. Hun havde spillet lidt klaver i sin ungdom, men ønskede sig at kunne spille i sociale sammenhænge. Nogle af de andre klubmedlemmer opmuntrede Marianne til at starte en sanggruppe, som kunne mødes et par gange om måneden i klubben. Marianne var usikker i sit spil og på sig selv, men sprang ud i det. Lederen hjalp efterfølgende med at søge nogle fondsmidler til klaverundervisning til Marianne. Klavertimerne hjalp på Mariannes klaverspil og på hendes tillid til at kunne løfte opgaven som tovholder og pianist for sanggruppen. Med tiden har Marianne fået det som fast opgave at akkompagnere fællessange til festlige lejligheder i klubben og fortsætte sanggruppen, som er blevet en fast aktivitet, der er åben for alle medlemmer. Ved at støtte Marianne i ønsket om at udvikle sit klaverspil og sørge for, at hun både fik musikalsk og moralsk opbakning, fik Marianne et pædagogisk puf til at udvikle sig samtidig med, at klubben fik en ny fast aktivitet og en pianist til fællessang. Ligesom eksemplet med Kaj, gav et pædagogisk puf anledning til personlig udvikling og glæde for såvel et enkelt menneske som for klubben og medlemmerne som helhed. I begge tilfælde handler det om at have fornemmelse for, hvor der er et potentiale hos den enkelte og en åbning for forandring til gavn for individet og fællesskabet. Denne slags pædagogiske initiativer skaber merværdi i klubben både individuelt og kollektivt, men det er ligesom oplevelsesklubben med til at give ældre mennesker en grund til at komme væk fra deres hjem, være sammen med andre mennesker og gøre en forskel i de fællesskaber, de er en del af, hvilket også er bæredygtigt for det bredere samfund.

Bæredygtighed kan være for individet og for samfundet eller sundheds- og plejesystemet. Nogle gange er interesserne sammenfaldende, og andre gange er 
de ikke. Bæredygtighed kræver en diskussion af, hvad der er af værdi og dermed værd at stræbe efter. Man kan overveje om en åben, men mere tidskrævende pædagogisk tilgang til det enkelte ældre menneske måske kan være både politikoøkonomisk og livskvalitetsforøgende bæredygtig på længere sigt.

Eksemplerne viser pædagogiske tilgange, hvor det enkelte ældre menneske identificeres som en ressourcefuld person med egen beslutningskompetence. Selvom eksemplerne kommer fra meget forskellige kontekster og handler om folk med vidt forskellige funktionsniveauer, har de det til fælles, at de foregår inden for nogle meget overordnede rammer, og hvor detaljerne i aktiviteten bestemmes af deltagerne. Der er tillid til, at deltagerne kan udfylde rammerne, men der er mulighed for situationsbestemt pædagogisk hjælp og støtte i tilfælde af, at det skulle være nødvendigt. I eksemplerne ser vi, hvordan fokus på overordnede rammer og individuelle ønsker og behov med tilpasset støtte ser ud til at kunne føre til bæredygtighed på et kollektivt plan. De ældre mennesker i eksemplerne tilegner sig nye kompetencer eller gentilegner sig mistede kompetencer, mens de bidrager til et meningsfuldt fællesskab. Deres deltagelse og bidrag på egne præmisser medfører tilsyneladende nogle af de resultater, som ellers ofte ønskes opnået gennem en sundhedsfokuseret pædagogik. I forhold til nogle mennesker giver et fokus på fysisk sundhed og selvhjulpenhed mening for det enkelte menneske og er bæredygtigt $\mathrm{i}$ betydningen positive og holdbare resultater. I mange sammenhænge er resultater af en sundhedsfokuseret pædagogik ikke holdbar, fordi sundheden i en snæver forstand ikke nødvendigvis har topprioritet i det enkelte menneskes liv (cf. Nørtoft 2013). Med en mere individualiseret pædagogisk tilgang, hvor det enkelte menneskes egne værdier og autonomi er i højsædet, tyder disse eksempler dog på, at man kan nå holdbare positive resultater vedrørende sundhed og dermed også samfundsøkonomi.

\section{Skal alderdommen pædagogiseres?}

De ovenfor skitserede perspektiver på ældrepædagogik viser, at de alle tre kan gribes forskelligt an alt efter hvilke værdier, man som samfund, professionel og individ sætter højest. Der findes ikke én enkelt opskrift på det gode ældreliv eller på vejen dertil, som passer til alle. Definitionen af det gode afhænger af værdier. Af og til er forskellige interessenters værdier og mål sammenfaldende, mens de andre gange er i direkte modstrid med hinanden. Dette ses tydeligt i de præsente- 
rede eksempler fra ældrepædagogiske kontekster. De kan opleves, forstås og værdisættes meget forskelligt.

Der er ingen tvivl om, at mange politikker på ældreområdet er guidet af et mere eller mindre snævert syn på fysisk sundhed, og i praksis skal mange af disse politikker og retningslinjer varetages af professionelle, som er uddannet inden for sundhedsområdet. I kombination med en dominerende økonomisk diskurs i samfundet er det ikke overraskende, at der er stort fokus på de økonomiske konsekvenser af ældrebefolkningens evner til at tage vare på sig selv og i øvrigt holde sig raske og selvhjulpne så længe som muligt. Spørgsmålet er dog, om et sådan fokus også er det mest bæredygtige for såvel samfundsøkonomi som individuel livskvalitet. Eksemplerne på ældrepædagogik i dette kapitel viser dog også stor variation i de pædagogiske tilgange på trods af, at flere af eksemplerne kommer fra sammenlignelige institutionelle kontekster, som er styret af samme politikker. Dette sker, fordi der trods alt er manøvrerum for den enkelte professionelle til at påvirke den mellemmenneskelige pædagogiske relation mellem den professionelle og det enkelte ældre menneske i det personlige møde.

Hvis man mener, at ældrepædagogik bør være mere og andet end sundhedspædagogik, må man arbejde med udviklingen af feltet som et selvstændigt felt ligesom det er sket i Sverige. Siden Hansen (2000) og Møller (2000) slog til lyd for udviklingen af en egentlig ældrepædagogik, har der ikke været meget teoretisk udvikling på området. Som det ses af denne artikel, har det dog ikke betydet, at alderdommen er fri for at blive pædagogiseret i det danske samfund - snarere tvært imod. Det er individuelt, hvad det enkelte menneske ønsker sig og finder meningsfuldt i hverdagen. Det betyder, at et snævert fokus på sundhed - selv i en bred forstand - langt fra er en konstruktiv tilgang over for alle. En mere bæredygtig tilgang til aldring vil derfor være en tilgang, der giver plads til, at individet bestemmer værdi og retning i sit eget liv og tilbydes nogle overordnede rammer og individuelt tilpasset støtte til at bevæge sig mod målet. Der er stor sandsynlighed for, at denne tilgang også vil føre til økonomisk bæredygtighed, fordi motivationen for at holde sig i gang, være en del af et fællesskab og bidrage med egne ressourcer vil være langtidsholdbar for langt flere end dem, som i forvejen har fysisk sundhed og sund livsstil prioriteret højt i det daglige, og som derfor har glæde af den sundhedsfokuserede pædagogik. Den mere individbaserede tilgang giver plads til det meste og til det, der er meningsfuldt for hver enkelt person. Derfor udelukker den heller ikke de andre pædagogiske tilgange, hvis disse vel at mærke er det, den enkelte har brug for. Men den udelukker, at en bestemt pædagogisk tilgang og et bestemt værdisæt kan bruges bæredygtigt over for alle. 


\section{Noter}

1. Empirien er som nævnt genereret i forskellige forskningsprojekter, men også gennem forskellige feltmetoder. Ph.d.-projektet var primært baseret på deltagerobservation (Spradley 1980), hvori samtaler med individer og grupper indgik som en naturlig del (Rubow 2003) i det fælles rum, som skabtes igennem samvær og fælleserfaringer (Hastrup 2010). Projektet om at flytte på plejehjem var et interviewbaseret studie (Tanggaard and Brinkmann 2009), og projektet om de forskellige grupper af professionelle i ældreplejen byggede på fokusgrupper (Halkier 2010) baseret på videomateriale (Nørtoft og Nordentoft 2019, Nørtoft og Hansen 2013).

2. Filmklippet er lavet af visuel antropolog Anne-Katrine Hansen (se evt. Nørtoft og Hansen 2013), og fokusgrupperne blev gennemført i samarbejde med vejledningsforsker Helle Nordentoft.

3. http://www.biyun.dk/om-biyunmetoden

4 En basisform inden for Biyun-metoden

5. http://ec.europa.eu/danmark/eu-politik/alle_emner/sociale/2010/101126_aldredom_ da.htm

https://dsr.dk/politik-og-nyheder/det-mener-dsr/tid-til-kvalitet-fire-forslag-til-et-merebaeredygtigt-3

6. http://www.menighedsplejer.dk/index.php?id=306

7. Feltarbejdet i klubben foregik i 2010 og 2011.

\section{Referencer}

Adams, Kathy B., Amy Restorick Roberts \& Marilyn B. Cole (2010): Changes in Activity and Interest in the Third and Fourth Age: Associations with Health, Functioning and Depressive Symptoms. Occupational Therapy International, nr. 18, s. 4-17.

Algreen-Petersen, Eva (2011): »Kan man flytte solen? « Et aktionsforskningsprojekt om at bringe naturen ind $i$ hverdagen på plejehjem. Ph.d.-afhandling, Institut for Miljø, Samfund og Rumlig Forandring, Roskilde Universitet.

Den Danske Ordbog (14/12 - 2018): https://ordnet.dk/ddo/ordbog?query=b\%C3\%A6redygtig

Den store danske (14/12- 2018): http://denstoredanske.dk/Erhverv,_karriere_og_ledelse/ P\%C3\%A6dagogik_og_uddannelse/P\%C3\%A6dagogik,_didaktik_og_metodik/ p\%C3\%A6dagogik

Fristrup, Tine (2010): Hvem er bange for de gamle? Danskernes Akademi, DR.

Fristrup, Tine (2013): Senlivets (u)beboelighed, i Finnur Magnússon, Jonas Christensen \& Anne Liveng (red.): CareSam. Aldrande och utmaningar $i$ Öresundsregionen - Att arbeta med xldre i Sverige och Danmark, s. 145-175, Malmö Högskola.

Halkier, Bente (2010): Fokusgrupper, i: Brinkmann, Sven \& Lene Tanggaard (red.) Kvalitative metoder, Hans Reitzels Forlag, København, s. 121-136.

Hansen, Helle Krog (2000): Et forsvar for begrebet ældrepædagogik. Dansk Pædagogisk Tidsskrift, nr. 3, 2000, s. 104-109.

Hastrup, Kirsten (2010): Feltarbejde, i: Brinkmann, Sven \& Lene Tanggaard (red.) Kvalitative metoder, Hans Reitzels Forlag, København, s. 55-80 
Hepworth, Mike (1995): Positive Ageing. What is the Message?, i Bunton, Robin, Sarah Nettleton \& Roger Burrows (red.): The Sociology of Health Promotion. Critical Analyses of Consumption, Lifestyle and Risk, s. 175-188, Routledge.

Higgs, Paul et al. (2009): Not just old and sick - the 'will to health' in later life. Ageing $\mathcal{E}$ Society, nr. 29, s. 687-07. https://doi.org/10.1017/S0144686X08008271

Jenkins, Richard (2008): Social Identity, Routledge, London and New york.

Københavns Kommune (2011): Aktiv og tryg hele livet. Et reformprogram for ældrepleje og sundhed $i$ Københavns Kommune. Københavns kommune, Sundheds- og omsorgsudvalget.

Knight, Tess \& Lina A. Ricciardelli (2003): Successful aging: Perceptions of adults aged between 70 and 101 years. International Journal of Aging and Human Development, Vol. 56, nr. 3, s. 223-245. https://doi.org/10.2190/CG1A-4Y73-WEW8-44QY

Lassen, Aske Juul \& Tiago Moreira (2014): Unmaking old age: Political and cognitive formats of active ageing, Journal of Aging Studies, Vol. 30, pp. 33-46 https://doi.org/10.1016/j. jaging.2014.03.004

Liveng, Anne (2013): Fremtidens ældre og omsorgen for dem - byrde eller guldgrube?, i Finnur Magnússon, Jonas Christensen \& Anne Liveng (red.): CareSam. Åldrande och utmaningar i Öresundsregionen - Att arbeta med xldre i Sverige och Danmark, s. 145-175, Malmö Högskola.

Magnússon, Finnur (2013): Vems behov? »Nya« professioner på gammal grund, i Finnur Magnússon, Jonas Christensen \& Anne Liveng (red.): CareSam. Åldrande och utmaningar $i$ Öresundsregionen - Att arbeta med ældre i Sverige och Danmark, s. 50-62, Malmö Högskola.

Møller, Kurt Wissendorf (2000): Ældrepædagogik - et postindustrielt design, 2000 Dafolo Forlag.

Naaldenberg, Jenneken, Lenneken Vaandrager, Maria Koelen \& Cees Leeuwis (2010): Aging Populations' Everyday Life Perspectives on Healthy Aging: New Insights for Policy and Strategies at the Local Level. Journal of Applied Gerontology, s. 1-23.

Nielsen, Eva Bonde (1992): Ældrepædagogik - fortsat personlig udvikling hos ældre. Ældrepædagogik, Danmarks Pædagogiske Institut, s.6.

Nørtoft, Kamilla (2013): „Did you imagine that old people could be like this? « A Kaleidoscope of Ageing, Health and Processes of Identity in and Urban Danish Context. Ph.d.-afhandling, Institut for Uddannelse og Pædagogik, Århus Universitet.

Nørtoft, Kamilla (2014): En sund ældrepædagogik? Vera. Tidsskrift for pædagoger, nr. 69, December 2014, s. 17-21

Nørtoft, Kamilla \& Anne-Katrine Hansen (2013): Exploring visual media in the process of ethnographic fieldwork. The Unfamiliar. An Anthropological Journal, Vol. 3, nr. 1, s. 54-59.

Nørtoft, Kamilla \& Jeppe Læssøe (2009): Projekt Ældres Netværk: en evaluering af oplevelsesklubben i Samvirkende Menighedsplejer og den samlede indsats i Kongens Enghave. Danmarks Pædagogiske Universitetsskole, Århus Universitet.

Nørtoft, Kamilla \& Helle Nordentoft (2019/in press): Exposing Diversity, Visual Anthropology

Paúl, Constanca, Oscar Ribeiro \& Laetitia Teixeira (2012): Active Ageing: An Empirical Approach to the WHO Model. Current Gerontology and Geriatrics Research, Vol. 2012. https:// doi.org/10.1155/2012/382972

Rossen, Eileen K., Kathleen A. Knafl \& Meredith Flood (2008): Older Women's Perceptions of Successful Aging. Activities, Adaptation \& Aging, Vol. 32, nr. 2, s. 73-88, Routledge. https://doi.org/10.1080/01924780802142644 
Rowe, J. W. and R. L. Kahn (1997): Successful aging. The Gerontologist, Vol. 37, nr. 4, s. $433-$ 440. https://doi.org/10.1093/geront/37.4.433

Rubow, Cecilie (2003): Samtalen. Interviewet som deltagerobservation, i: Hastrup, Kirsten (red.), Ind i Verden. Grundbog i Antropologisk Metode, Hans Reitzels Forlag, København, s. $227-244$

Sagli, Gry (2008): Learning and Experiencing Chinese Qigong in Norway. East Asian Science, Technology and Society: an International Journal, Vol. 2, nr. 4, s. 545-566. https://doi. org/10.1215/s12280-009-9071-z

Spradley, James (1980): Participant Observation, Waveland Press, Inc., Long Grove, Illinois

Tanggaard, Lene \& Sven Brinkmann (2010): Interviewet. Samtalen som forskningsmetode, i: Brinkmann, Sven \& Lene Tanggaard (red.) Kvalitative metoder,Hans Reitzels Forlag, København, s. 29-54.

Tate, Robert B., Leedine Lah \& T. Edward Cuddy (2003): Definition of Successful Aging by Elderly Canadian Males: The Manitoba Follow-Up Study. The Gerontologist, Vol. 43, nr., 5, s. 135-744. https://doi.org/10.1093/geront/43.5.735

Thomasen, Louise Scheel (2009). En god alderdom? Aktivering af svækkede ældre i leve-og bomiljø. Specialerække nr. 517, Institut for Antropologi, Københavns Universitet.

Walker, Alan \& Maltby, Tony (2012): Active ageing: A strategic policy solution to demographic ageing in the European Union. International Journal of Social Welfare, XX, s. 1-10. https://doi.org/10.1111/j.1468-2397.2012.00871.x

WHO (2002). . WHO. 